This is an open-access article distributed under the terms of the Creative Commons Attribution License, which permits unrestricted use, distribution, and reproduction in any medium, provided the original author(s) and source are credited.

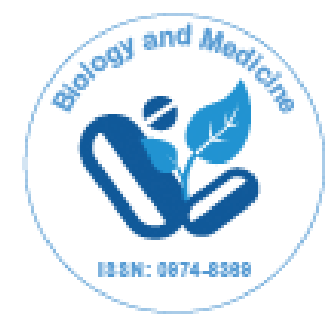

ISSN: 0974-8369

\title{
Biology and Medicine
}

\author{
International, Open Access
}

\section{Available online at: www.biolmedonline.com}

7 his article was originally published in this journal and the attached copy is provided for the author's benefit and for the benefit of the author's institution, for commercial/research/educational use including without limitation use in instruction at your institution, sending it to specific colleagues that you know, and providing a copy to your institution's administrator.

All other uses, reproduction and distribution, including without limitation commercial reprints, selling or licensing copies or access, or posting on open internet sites, your personal or institution's website or repository, are requested to cite properly. 


\title{
Milk Productivity and Natural Resistance of Holstein-breed Heifers of Own Generation
}

Beken Okenovich Alimzhanov*, Lyudmila Vasilevna Alimzhanova, Saule Kuanyshpekovna Bostanova, Yuliya Nikolayevna Sheiko, Saltanat Aytimovna Isabekova

S.Seifullin Kazakh AgroTechnical University, 62 Prospect Pobedy, Astana 010000, Republic of Kazakhstan

\begin{abstract}
The paper analyzes the milk production of Holstein breed of cattle imported from Canada to Kazakhstan. It is found that milk production of Holstein heifers in Northern Kazakhstan conditions is in high enough amounts: milk yield for 305 days of lactation of Canadian heifers is $6,627 \mathrm{~kg}$ and for the animals of own reproduction is $6,488 \mathrm{~kg}$. However, the acclimatization of Holstein cows is satisfactory, and they concede to the local animals of black-motley breed on reproductive qualities, especially on the duration of the service period. This is also evidenced by the birth of calves per 100 cows, which was $96.5 \%$ for black-and-white cattle, whereas this figure was $76.5 \%$ for imported Holstein cows, and it's increased to $78.8 \%$ for Holstein cows bred in the conditions of Northern Kazakhstan.
\end{abstract}

\section{Keywords}

Holstein; First-calf heifers; Lactation performance; Reproductive capacity; Service period; Natural resistance

\section{Introduction}

Holstein animals of Canadian breeding are characterized by a high potential of lactation performance, requiring comfortable nutrition and relevant animal welfare. The climate and vegetation in North Kazakhstan differ from Canada's; therefore, at the first stage, it is important to study acclimatization of imported purebred animals and at the second stage, adaptation of animals of own reproduction, that is, those that are born and bred in the natural biotope of Akmolinsk region of Kazakhstan. It is known that the higher the genetic potential productivity of imported livestock breeds, the more difficult is the process of cattle acclimatization to new weather and climate conditions of livestock breeding. Therefore, in order to facilitate the acclimatization process, it is necessary to perform a complex of zootechnical, environmental, and veterinary hygienic activities for rational use of such valuable breeding material for the purpose of retention of the imported livestock's genetic productivity and reproductive performance in regard to the new nutrition and for relevant animal welfare.

In different years, Bodunovskaya [1], Tulebayev [2], Alimzhanova and Bostanova [3], and others studied acclimatization of cattle stock of various breeds in the Republic of Kazakhstan.

The dairy industry in Canada is famous for the excellent genetic quality of herd and improvement of genetic-evaluation programs. Milk production in 2012 was on the average 9,780 kg per lactation (305 days) with an average fat content of $3.85 \%$ and protein content of $3.22 \%$ [4].

The Holstein breed is the most widely spread dairy breed and makes up $94 \%$ of the country's total dairy herd [5-9].

\section{Materials and Methods}

The studies were conducted in the farm of Rodina firm in the Akmolinsk region under climatic conditions typical for North Kazakhstan.

The Holstein first-calf heifers imported from Canada in 2007 served as the target of our research, as well as their female offspring obtained in Kazakhstan and local white-and-black cattle herd mates.

A research methodology of objective-reality-cognition process, a complex phenomenon of acclimatization of the Holstein livestock to the environmental conditions in North Kazakhstan, provided for a scientific approach of comparative study of imported animals as compared with the local livestock in similar feeding and technological conditions of one farm, ability for homeostasis retention by them that ensured normal life activity, and reproduction of a healthy generation.

This paper presents the material to study lactation performance, reproductive capacity, and natural resistance of purebred Holstein first-calf heifers as compared to white-and-black first-calf heifers with 5/8 blood of the Holstein breed. The experiment was conducted in compliance with the scientific ethical standards and principles; consequently, in analysis of the findings, we were guided by our own experimental data only, obtained in methodologically consistent significant experiments, which excluded data falsification, plagiarism, and false joint authorship.

To achieve the target, the experiment was conducted in the production conditions of Rodina farm, under natural weather and climatic conditions for animals. Feeding was mobile and done twice a day (5.00 a.m. and 5.00 p.m.). The ration basically consists of farm-produced fodder (velour grasses, silo, and mixed feed) turned into a mixture in a feed mixer and specially purchased supplements (concentrate, miravit, feeding sugar, crystalyx vinalux). The daily norm for the feed mixture was $40 \mathrm{~kg}$ [10].

A daily mixed-feed rate contains $21.4 \mathrm{~kg}$ of dry substance, including $4.6 \mathrm{~kg}$ of dietary fiber, $1.9 \mathrm{~kg}$ of protein, $1.3 \mathrm{~kg}$ of sugar, and $0.51 \mathrm{~kg}$ of fat. Macro and microelements, vitamins (carotene, D, and E), amino acids (lysine, methionine) have been balanced based on the needs for cows weighing 600 to $650 \mathrm{~kg}$ and a daily milk yield of $30 \mathrm{~kg}$.

*Corresponding author: Alimzhanov BO, S.Seifullin Kazakh AgroTechnica University, 62 Prospect Pobedy, Astana 010000, Republic of Kazakhstan; E-mail: naukabeken@mail.ru

Received: Feb 20, 2016; Accepted: Mar 17, 2016; Published: Apr 13, 2016

Citation: Alimzhanov BO, Alimzhanova LV, Bostanova SK, Sheiko YN, Isabekova SA (2016) Milk Productivity and Natural Resistance of Holstein-breed Heifers of Own Generation. Biol Med (Aligarh) 8(2): BM-171-16, 3 pages.

Copyright: (C) 2016 Alimzhanov et al. This is an open-access article distributed under the terms of the Creative Commons Attribution License, which permits unrestricted use, distribution, and reproduction in any medium, provided the original author and source are credited 
Citation: Alimzhanov BO, Alimzhanova LV, Bostanova SK, Sheiko YN, Isabekova SA (2016) Milk Productivity and Natural Resistance of Holsteinbreed Heifers of Own Generation. Biol Med (Aligarh) 8(2): BM-171-16, 3 pages.

Page 2 of 3

Technological groups are generated from a maternity barn. During the first lactation trimester, cows increase their milk yield, and mixed feed to them is increased by $30 \%$. After the period of increasing milk yield, animals are transferred to the next sections according to the daily milk-yield level (up to $25 \mathrm{~kg}$ and more than $25 \mathrm{~kg}$ of a daily milk yield). And during the last lactation trimester, cows are transferred to subsequent sections regardless of a daily milk yield. Besides, there are sections for cows not in milk and for heifers of breeding age.

For each technological group, a ration is chosen separately, according to the productivity of cows in each section.

The scientific experiment envisaged a whole series of more accurate laboratory studies of the chemical composition of milk, feed, and biochemical blood values. For this the following were identified:

- a milk yield for full lactation and milk composition under GOST 25179-90;

- hematologic values and natural resistance using analyzer Abacus junior vet 2007;

- cellular protection factor by opsonocytophagic reaction, humoral according to Munssen and Trefens in modification of O. Smirnova and G. Kuzmina;

- indices of reproductive capacity under the documents of primary zootechnical records of the farm.

Milk-producing records for completed lactation were performed based on the data of everyday milk-yield control in 405 first-calf heifers. Milk composition was analyzed in an average daily sample. Blood was taken from a jugular vein before feeding in the morning.

Livestock acclimatization in the new biotope was studied subject to the environmental ethics principles and rules. Nobel Peace Prize laureate Albert Schweitzer underlines that "Animals suffer as much as we do. Wherever any animal is forced into the service of man, the sufferings which it has to bear on that account are the concern of every one of us." Therefore, in the new biotope we created "comfortable" conditions for imported animals with regard to the feeding levels and management technology, which became one of the more important acclimatization techniques. Adherence to environmental ethics excluded cruel animal treatment in experiments.

Thus, the scientific production experiments ensured duration of observations and enhanced credibility of findings, and observations performed by seasons made it possible to take into consideration different combinations of weather factors of the environment. Such scientifically substantiated feeding for imported animals and animals of own reproduction and compliance with standards and rules of scientific and environmental ethics contributed to rational use of highproductive genotypes in the process of raising a number of generations in the biotope of North Kazakhstan new for them.

\section{Results and Discussion}

Lactation performance in the Holstein first-calf heifers turned out to be higher than in local herd mates by $32-35 \%$ (Table 1). But the dry substance content in the Holstein's milk is less than in local because of reduced lipid and protein content. Consequently, the milk caloric value turned out to be lower by $15-21 \mathrm{kcal} / \mathrm{kg}$.

First-calf heifer lactation curves are rather flat; average monthly drop in milk yields throughout lactation was about $5 \%$, but they are double-peaked in Holsteins. Apparently, it is associated with insufficient energy and protein supply during lactation.

\begin{tabular}{|c|c|c|c|}
\hline \multirow{2}{*}{ Parameters } & & \multicolumn{2}{|c|}{ Holsteins } \\
\cline { 3 - 4 } & Local & Canadian & $\begin{array}{c}\text { Own } \\
\text { generation }\end{array}$ \\
\hline Milk yield for 305 days, kg & $4,874 \pm 119^{*}$ & $6,627 \pm 207$ & $6,488 \pm 216^{*}$ \\
\hline Fat content, \% & $3.72 \pm 0.04$ & $3.60 \pm 0.03$ & $3.64 \pm 0.02$ \\
\hline Protein content, \% $^{*} 3.30 \pm 0.02$ & $3.03 \pm 0.02$ & $3.08 \pm 0.01$ \\
\hline Milk-fat quantity, kg & $181.3 \pm 9.2^{*}$ & $238.5 \pm 8.7^{*}$ & $236.2 \pm 12$ \\
\hline Milk-protein quantity, kg & $160.8 \pm 7.4^{*}$ & $200.8 \pm 6.2^{*}$ & $199.8 \pm 9.0$ \\
\hline Lactose, $\%$ & $4.87 \pm 0.03$ & $4.95 \pm 0.05$ & $4.91 \pm 0.04$ \\
\hline Minerals & $0.80 \pm 0.002$ & $0.75 \pm 0.004$ & $0.77 \pm 0.02$ \\
\hline Dry substances, g & $12.69 \pm 0.06$ & $12.33 \pm 0.08$ & $12.40 \pm 0.07$ \\
\hline Density, ${ }^{\circ} \mathrm{A}$ & $29.4 \pm 0.11$ & $29.1 \pm 0.08$ & $29.3 \pm 0.06$ \\
\hline Acidity, ${ }^{\circ} \mathrm{T}$ & $17.8 \pm 0.13$ & $17.6 \pm 0.06$ & $17.7 \pm 0.03$ \\
\hline Caloric value, $\mathrm{kcal} / \mathrm{kg}$ & $703 \pm 24$ & $682 \pm 30$ & $688 \pm 31$ \\
\hline
\end{tabular}

Table 1: Lactation performance and milk composition in first-calf heifers

\begin{tabular}{|c|c|c|c|}
\hline \multirow[b]{2}{*}{ Parameters } & \multirow[b]{2}{*}{ Local } & \multicolumn{2}{|c|}{ Holsteins } \\
\hline & & Canadian & $\begin{array}{l}\text { Own } \\
\text { Generation }\end{array}$ \\
\hline Erythrocyte, $10^{12} /$ & $6.72 \pm 0.35$ & $6.30 \pm 0.21$ & $6.96 \pm 0.24$ \\
\hline Hemoglobin, g/l & $119 \pm 0.70$ & $136.8 \pm 0.52$ & $148.6 \pm 1.1$ \\
\hline Acid capacity, mg\% & $530 \pm 3.5$ & $501 \pm 4.7$ & $542 \pm 3.8$ \\
\hline $\begin{array}{l}\text { Erythrocyte sedimentation } \\
\text { rate }(E S R), \mathrm{mm} / \mathrm{h}\end{array}$ & $0.33 \pm 0.04$ & $0.58 \pm 0.06$ & $0.50 \pm 0.03$ \\
\hline Leukocyte, $10 \%$ & $7.12 \pm 0.06$ & $12.43 \pm 0.9$ & $7.6 \pm 0.80$ \\
\hline Total protein, g/l & $85.7 \pm 2.4$ & $83.9 \pm 0.11$ & $84.4 \pm 0.20$ \\
\hline Including albumin & $33.6 \pm 1.9^{*}$ & $32.5 \pm 1.1$ & $27.3 \pm 2.0^{*}$ \\
\hline$\alpha$-globulin & $16.8 \pm 0.9$ & $18.1 \pm 1.5$ & $15.0 \pm 0.6$ \\
\hline$\beta$-globulin & $17.8 \pm 2.2^{*}$ & $25.3 \pm 1.4$ & $32.7 \pm 2.9$ \\
\hline$\gamma$-globulin & $31.9 \pm 2.7$ & $24.1 \pm 2.8$ & $25.0 \pm 2.2$ \\
\hline Phagocytic activity, \% & $64.2 \pm 1.7^{*}$ & $58.3 \pm 2.1$ & $54.0 \pm 4.1^{*}$ \\
\hline Phagocytic index & $6.1 \pm 0.03$ & $8.5 \pm 0.11$ & $8.7 \pm 0.19$ \\
\hline Phagocytic number & $2.3 \pm 0.02$ & $5.6 \pm 0.2$ & $4.6 \pm 0.11$ \\
\hline Bactericidal activity, \% & $66.3 \pm 2.8$ & $64.1 \pm 0.5$ & $65.2 \pm 7.0$ \\
\hline Lysozyme activity, \% & $16.3 \pm 1.1^{*}$ & $9.6 \pm 1.0$ & $8.0 \pm 0.8^{*}$ \\
\hline
\end{tabular}

${ }^{*} p \leq 0.05$

Table 2: First-calf heifers blood values

The milk gland is intensely supplied with blood, and the quantity of milk generated and its quality depend upon full-value blood.

Table 2 shows blood status characterizing oxidation-reduction processes in the organs of animals acclimatized.

It is seen that the blood of Holstein animals is well saturated with blood corpuscles, providing normal metabolism in their organisms.

Thus, the data in Table 2 show an erythrocyte and hemoglobin growth trend in the blood of the female offspring as compared with the mothers, accumulation of circulatory buffers in organisms. At the same time, an erythrocyte sedimentation rate is 1.5 times higher in imported animals than in local animals. The Holstein first-calf heifers were characterized by an increased specific weight of $\beta$-globulins but conceded in $\gamma$-globulins (24-25\% versus 32\% in local animals).

A strong impact of the ambient environment was especially made on the organisms of imported first-calf heifers. In their blood there were $12.4 \times 10 \%$ leukocytes, and in the female offspring the number had already reduced to the level of local animals $\left(7.6 \times 10^{\%} /\right)$. 
Citation: Alimzhanov BO, Alimzhanova LV, Bostanova SK, Sheiko YN, Isabekova SA (2016) Milk Productivity and Natural Resistance of Holsteinbreed Heifers of Own Generation. Biol Med (Aligarh) 8(2): BM-171-16, 3 pages.

Page 3 of 3

\begin{tabular}{|c|c|c|c|}
\hline & & \multicolumn{2}{|c|}{ Holsteins } \\
\cline { 2 - 4 } Parameters & Local & Canadian & $\begin{array}{c}\text { Own } \\
\text { generation }\end{array}$ \\
\hline $\begin{array}{c}\text { Duration of a service period, } \\
\text { days }\end{array}$ & $98 \pm 3.8$ & $205 \pm 16.0$ & $189.8 \pm 8.5$ \\
\hline Intercalving period, days & $373 \pm 16$ & $478 \pm 19$ & $464 \pm 21$ \\
\hline Reproductive ability ratio & 1.02 & 1.30 & 1.27 \\
\hline Mating index & $1.34 \pm 0.10$ & $1.82 \pm 0.40$ & $1.65 \pm 0.24$ \\
\hline Calf crop per 100 cows, \% & 96.5 & 76.5 & 78.8 \\
\hline Calf crop body weight, kg & $31.2 \pm 0.7$ & $38.5 \pm 1.5$ & $33.2 \pm 2.1$ \\
\hline Body weight at six months, kg & $147.0 \pm 1.8$ & $183.6 \pm 2.7$ & $177.3 \pm 3.4$ \\
\hline $\begin{array}{c}\text { An average daily body weight } \\
\text { gain, g }\end{array}$ & $643 \pm 15$ & $805.5 \pm 16$ & $774.4 \pm 25$ \\
\hline $\begin{array}{c}\text { Calf livability by six-month } \\
\text { age, \% }\end{array}$ & 98.8 & 85.3 & 88.6 \\
\hline
\end{tabular}

Table 3: First-calf heifers reproductive capacity

One of the most important factors of the animals adaptation to the new living environment is the state of their natural resistance. Cellular protection factors in Holsteins were at $54-58 \%$ with neutrophilic granulocyte aggressivity at 8.5 to 8.7 , and phagocytosis in local first-calf heifers was $64.2 \%$.

Out of humoral protection factors, bactericidal activity of blood serum in all the animals was practically at the same level (64-66\%), while lysozyme activity was lower in Holsteins (8-9\% vs. $16 \%$ in locals).

One of the most objective tests of animal positive acclimatization is a state of their reproductive system. It is in this system that an organism's failure occurs in the first place under adverse environmental factors. Indeed, during the first winter of habitation in Kazakhstan calving was very hard. A retained placenta was observed in every third animal; by spring this process was aggravated by the development of metritis that required long-term treatment. As a result, a service period was 205 days (Table 3) and intercalving period was 478 days.

The service period in daughters reduced by 16 days but it still remains high, while in local heifers its duration is 98 days.

In daughters, mating index reduced to 1.65 as compared to mothers; calf crop increased to $78.8 \%$ and their livability in the lactation period grew by $3.2 \%$.

As it is seen from the provided material, there exists a trend of improvement in the parameters of the female offspring versus those of the mothers, but a reproduction problem still remains. It seems that interlactation period should be extended for Holsteins in order to recover and make stock replacement for the next lactation.

Thus, it may be concluded that the acclimatization process of Holsteins imported from Canada to Kazakhstan is complicated.
Milk yield of imported first-calf heifers was $6,627 \mathrm{~kg}$ at milk fat content of $3.6 \%$ and protein content of $3.03 \%$. Their female offspring in the first lactation produced $6,488 \mathrm{~kg}$ each with fat content of $3.64 \%$ and protein content of $3.08 \%$.

After calving, animals have a long recovery time (service period of mothers is 205 days; female offspring, 189 days). Mating index in Holsteins is high and their calf crop is lower compared to local animals.

Hematological values are within the range of a physiological standard; however, $\gamma$-globulin and cellular protection factor content is lower than in local animals.

\section{Conclusions}

1. Lactation performance in Holstein first-calf heifers in the new biotope in Akmolinsk region of Kazakhstan is rather high and is as follows: milk yield for 305 days of lactation is $6,627 \mathrm{~kg}$ in Canadian heifers and $6,488 \mathrm{~kg}$ in animals of own reproduction.

2. First-calf heifers, both purebred and of own reproduction, are inferior in reproductive characteristics to local animals of a black-and-white breed, especially in terms of duration of service period. It shows that the acclimatization process was strained for these animals.

3. In future work with imported livestock, special attention should be paid to reproductive features of animals being acclimatized by appropriate feeding and conditions of detention in the new biotope subject to perspective functions of their organisms.

\section{References}

1. Bodunovskaya NS (1978) Acclimatization of Red Estonian and Brown Latvian livestock. Dairy and beef cattle breeding of North Kazakhstan. Alma-Ata, pp. 52-57.

2. Tulebayev B (1989) Adaptability of Alatau cows of various genotypes depending on the milk productivity rate: dissertation Candidate of Science (Agriculture). Alma-Ata, p. 22

3. Alimzhanova LV, Bostanova SK (2005) Lactation performance, hematologica values, natural resistance of cows imported from Kemerovo region and their decendents obtained in Kazakhstan. Bishkek, p. $105 \mathrm{~V}(1)$.

4. Canadian Dairy Information Centre. www.dairyinfo.gc.ca

5. Salakhov I (2002) The adaptational ability and using of a genefond of the Hungarian Golshtinsky cattle in Tatarstan. Candidate thesis. Kazan, p. 128.

6. Alencar M, Bugner M (1987) Desetpeho Produtio de femeas das racas canchim e-nelore-Resguisa Adropecuaria Bsasillira. Embrapa 22(8): 867-872.

7. (2011) The imported dairy cattle in Russia: the features of adaptation and cattle management. Agrarian Rev (5) p. 85.

8. Prendiville R, Pierce KM, Delaby L, Buckley F (2011) Animal performance and production efficiencies of Holstein-Friesian, Jersey and Jersey $\times$ Holstein Friesian cows throughout lactation. Livestock Sci 138: 25-33.

9. Tamarova R, Kanareykin N (2010). The adaptational and productive qualities of imported and domestic cattle at free stabling. Dairy Meat Cattle Breed 1: 8-9.

10. Kirnos I, Suslova I, Duborezov V (2011) The adaptive system of feeding-a controlling factor in the realization of genetic potential of cows efficiency Zootechnics 9: 9-11.

Submit your next manuscript and get the following advantages

Special features:

30 days rapid review process

Quality and quick editorial, review and publication processing

Indexing at Scopus, EBSCO, ProQuest, Gale Cengage, and Google Scholar etc

Authors, Reviewers and Editors rewarded with online Scientific Credits

- Better discount for your subsequent articles

Submit your manuscript at: submissions@biolmedonline.com 